\begin{tabular}{|c|l|}
\hline Title & $\begin{array}{l}\text { Discovery of the genus Suhpal acsa L efèbvre (Neuroptera: A scal aphidae: A scal aphinae) in Japan, with description of a } \\
\text { new species }\end{array}$ \\
\hline Author(s) & Sekimoto, Shigey uki; Y oshizawa, Kazunori \\
\hline Citation & $\begin{array}{l}\text { Entomological Science, 10(1), 81-86 } \\
\text { https://doi.org/10.1111/.1479-8298.2006.00201.x }\end{array}$ \\
\hline Issue Date & 2007-03 \\
\hline Doc URL & http://hdl.handle.net/2115/35634 \\
\hline Rights & The definitive version is available at www.blackwell-synergy.com \\
\hline Type & article (author version) \\
\hline File Information & Yoshizawa9.pdf \\
\hline
\end{tabular}

Instructions for use 


\section{Unpublished for the purposes of Zoological Nomenclature (ICZN Art. 8.2)}

$\$=$ male $\#=$ female

Discovery of the genus Suhpalacsa Lefèbvre (Neuroptera:

Ascalaphidae: Ascalaphinae) in Japan, with description of a new species

Shigeyuki SEKIMOTO and Kazunori YOSHIZAWA

Systematic Entomology, Department of Ecology and Systematics, Graduate School of Agriculture, Hokkaido University, Sapporo, Japan

Correspondence: Kazunori Yoshizawa, Systematic Entomology, Department of Ecology and Systematics, Graduate School of Agriculture, Hokkaido University, Kita-9, Nishi-9, Sapporo, 060-8589 Japan

Telephone: 011-706-2424

Fax: 011-706-4939

Email: psocid@res.agr.hokudai.ac.jp

Short running title: New Suhpalacsa species from Japan 


\title{
Discovery of the genus Suhpalacsa Lefèbvre (Neuroptera: Ascalaphidae: Ascalaphinae) in Japan, with description of a new species
}

\author{
Shigeyuki SEKIMOTO and Kazunori YOSHIZAWA \\ Systematic Entomology, Department of Ecology and Systematics, Graduate School of \\ Agriculture, Hokkaido University, Sapporo, Japan
}

\begin{abstract}
Suhpalacsa iriomotensis sp. nov. (Neuroptera: Ascalaphidae: Ascalaphinae), is described from Iriomotejima Is., Japan. This new species can be easily distinguished from other species of the genus by the unique ventrolateral prominences of the male ectoproct. This is the first record of the genus Suhpalacsa from Japan. Morphology of the male ectoproct and monophyly of Suhpalacsa are briefly discussed.
\end{abstract}

Key words: Ascalaphidae, new species, Suhpalacsa iriomotensis, the Ryukyus, taxonomy.

\section{INTRODUCTION}

The family Ascalaphidae (owl flies) contains approximately 400 species assigned to 65 genera with wide distributional range in warm regions of the world. Adults are fast flying predators inhabiting grasslands and warm dry woodlands and are characterized by large eyes and long antennae with distinct apical club. Most species are nocturnal or crepuscular and sometimes attracted by light except for some diurnal Eurasian ones. The family is subdivided into three subfamilies: Haplogleniinae, Ascalaphinae and Albardiinae. Albardiinae consist of a single, very rare, large-sized Brazilian species. The other two major subfamilies are characterized by fundamental character of eyes, 
compound eyes divided dorsoventrally by a transverse furrow (Ascalaphinae) or not (Haplogleniinae).

In Japan, taxonomic studies of Ascalaphidae were carried out in late 19th to early 20th century (McLachlan 1871, 1875, 1891; Okamoto 1909). To date, four species assigned to four genera are known from Japan: one haplogleniine species, Libelluloides ramburi (McLachlan, 1875), and three ascalaphine species, Ascalohybris subjacens (Walker, 1853), Protidricerus japonicus (McLachlan, 1891) and Suphalomitus okinavensis (Okamoto, 1909). Although some new distributional records were added subsequently (Kuwayama 1962, 1964), no species has been added to Japanese fauna since 1909. According to the checklist of Japanese insects (Nomura 1989), the ascalaphid fauna of Japan is generally considered to be well investigated and understood.

Recently, we examined some ascalaphid specimens collected in Iriomotejima Is. that could not be identified as the previously known Japanese species of Ascalaphidae. By the detailed examination of the specimens, we confirmed that they represent a new species of the ascalaphine genus Suhpalacsa Lefèvre, 1842. The genus includes 36 species distributed in Africa, Asia and Australia. Of these, 14 species are known from Asia and New Caledonia (Sziráki 1998). In eastern Asia, S. formosana Okamoto, 1909 and S. umbrosa Esben-Petersen, 1913 are known from Taiwan, and $S$. longialata Yang, 1992 is known from Hunan, China. In this paper, we describe the new species of Suhpalacsa and briefly discuss morphology of the male ectoproct and monophyly of Suhpalacsa. This is the first record of the genus Suhpalacsa from Japan.

\section{MATERIALS AND METHODS}

All specimens used in this study were dried. For the detailed observation of the genitalia, the terminal segments of abdomen were removed and placed in $10 \%$ solution 
of $\mathrm{KOH}$ at room temperature for approximately $12-24$ hours, then washed with distilled water and stained with aceto-fuchsin. After that, the materials were transferred into distilled water, and dissected and observed under a binocular stereoscopic microscope.

Terminology follows Tjeder (1992). The following abbreviations are used: B = body length, $\mathrm{A}=$ antenna length, $\mathrm{FW}=$ forewing length, $\mathrm{HW}=$ hindwing length, Ta1-Ta5 $=$ first to fifth tarsomeres. All measurements are given in millimeters.

All specimens including the holotype are deposited in the Laboratory of Systematic Entomology, Hokkaido University, Sapporo, Japan (SEHU).

\section{TAXONOMY}

\section{Genus Suhpalacsa Lefèbvre, 1842}

Suhpalacsa Lefèvre, 1842: 7. Type species: Ascalaphus flavipes Leach, 1814: 48, subsequent designation by Van der Weele, 1909: 158.

Ceraus Navás, 1900: 95. Type species: Ascalaphus flavipes Leach, 1814: 48, subsequent designation by Oswald, 1988: 91. Synonymized by Oswald, 1988: 91.

Diagnosis. Antenna straight, unornamented, about 3/4 as long as forewing, shorter than distance between base of forewing and pterostigma; wings generally elongate and narrow, anterior and posterior margins almost parallel, venation not dense; forewing longer and slightly wider than hindwing; pterostigma short, distinct, quadrilateral; apical area of wings broad, with two or three rows of cells; anal margin of forewing rounded or slightly angled, not produced; spurs about as long as or longer than Ta1; male without dorsal abdominal prominence; male ectoproct usually scale-like, sometimes ornamented; gonarcus usually not hooded; parameres small, usually hook- 
like.

Remarks. Members of the genus are superficially very similar to each other. Several species show sexual dimorphism in wing shape and abdominal length: i.e., wings of males tend to have more rows of cell in the posteroproximal region of one or both wings (New 1984), and male abdomen is longer than that of the female. Suhpalacsa is considered to be closely related to Suphalomitus Van der Weele, 1909 but can be distinguished from it by the relatively longer hindwing and shorter pterostigma (in Suphalomitus, the hindwing is noticeably shorter than forewing and pterostigma is long). However, New (2003) pointed out that the systematic positions of some Malesian species originally assigned to Suhpalacsa or Suphalomitus need to be revised.

\section{Suhpalacsa iriomotensis, sp. nov}

(Figs 1-9)

Holotype. \$, “<Ryukyus $>$, Is. Iriomotejima, Funaura, 11.v.1993, K. Yoshizawa leg.”. Paratypes. [Ryukyus] 7\$9\#, same date as holotype; $1 \$ 14 \#$, same locality as holotype, 13.v.1993, K. Yoshizawa.

Male. Head. Slightly wider than thorax. Vertex pale brown, narrower than diameter of eye in dorsal view, with dense long grayish-white and dark hairs; occiput brown, bare, dorsal margin yellow to pale brown; frons brown, with dense tufts of long grayishwhite and dark hairs laterally; gena brown, except for narrow pale to yellow band along eye margin, bare; clypeus yellow, with moderately long grayish-white and some dark hairs; postorbital sclerites pale to yellow, dorsally dark, bare; pleurostoma present. Antenna pale brown; scape brown, with dense long grayish-white and some dark hairs; pedicel brown, with some long grayish-white hairs apically; base of first flagellum dark brown; club dark brown to blackish-brown, often with yellow portion laterally, with short black hairs; flagellum comprising about 45-50 segments, each 
flagellum with few very short hairs apically. Mouthparts yellow; labrum pale brown with pale brown hairs; mandible dark brown at apex, with sparse grayish-white hairs basally; cardo and stipes largely brown, with long pale yellow and dark hairs, 3rd to 5th maxillary palpomeres brown to dark brown; labium with long pale yellow and dark hairs, 2nd and 3rd labial palpomeres brown to dark brown, 3rd labial palpomere with sensory pit.

Thorax. Pronotum dark grayish-brown, sometimes with yellow portion anteromedialy, moderately covered with long grayish-white and dark hairs, with lateral prominences bearing hair-tufts. Mesonotum and metanotum dark grayish-brown, with yellow median spots on mesoprescutum, mesoscutellum, and often on metanotum, moderately covered with long grayish-brown and pale gray hairs, mixed with dark hairs on metanotum. Mesopleuron and metapleuron dark grayish-brown, with yellow longitudinal band on each pleuron ventrally not continuous, densely covered with long white hairs, mixed with grayish-brown hairs on mesoanepisternum and mesoanepimeron.

Legs. Coxae dark gray, densely covered with long white hairs; femora pale brown to brown, moderately covered with long white hairs and black setae, fore and mid femora yellowish on about basal 1/3-1/2 dorsally; tibiae about as long as femora, brown, often dark brown to blackish-brown at apex, moderately covered with black setae and short black hairs, fore tibia with short brown hairs on anterior surface; spurs reddish-brown, slightly curved, in fore and mid legs about as long as combined length of Ta1-Ta2 to Ta1-Ta3, in hind leg about as long as Ta1 to combined length of Ta1Ta2; tarsi slightly shorter than tibiae, reddish-brown to blackish-brown, Ta1-Ta4 short, Ta5 long, with short black hairs dorsally, short black setae ventrally, in fore and mid legs Ta1 as long as Ta2, Ta5 as long as combined length of Ta1-Ta4, in hind leg Ta1 as long as combined length of Ta2-Ta3, Ta5 shorter than combined length of Ta1Ta4; claws reddish-brown, curved, about $2 / 3$ as long as spurs. 
Wings. Rounded at apex. Membrane bare, without markings. Pterostigma transparent to pale brown, with three to four black crossveins. Veins and wing margins with very short black hairs, except for posteroproximal margin of hindwing with long grayish-brown hairs. Veins dark brown, Sc and R1 pale yellow to pale brown, $\mathrm{M}$ and $\mathrm{Cu} 1$ pale brown. Apical area usually with two rows of cells, rarely with three rows. Presectoral area with five to eight crossveins and zero to two irregular double cells in forewing, with three to five crossveins and zero to one irregular double cells in hindwing.

Abdomen. Dark gray, longer than hindwing, densely covered with short black setae, tergites II to VII with small orange spot posteroventrally, sternite II largely yellow, pair of yellow elongate spots on sternite III sometimes fused medially or separated, sternites III to VII yellow to orange along posterior margin, sternite VII and anterior half of sternite VIII sometimes with white powder, sternites II and III with long white hairs.

Male terminalia (Figs 2-4): ectoproct with ventrolateral prominences bearing some long black setae. Genitalia (Figs 5-7): gonarcus shallow, elongate, slender; parameres not hooked, with rather rounded apex, fused to gonarcus basally with distinct suture; pelta small; pulvinus short, flattened, with dense long black gonosetae.

Length: B, 33-37; A, 16-19; FW, 24-28; HW, 20-23.

Female. Coloration and general morphology, including wing venation, except terminalia, almost as in male, but pterostigma darker, pale brown to dark brown; abdomen much shorter, shorter than hindwing; pair of yellow spots of sternite III often smaller or almost indistinct; sternites VII and VIII not covered with powder; pleural membrane often with yellow to orange spots.

Terminalia (Figs 8-9): ectoproct simple; ventrovalvae long, expanded 
posteriorly; interdens present; linguella well developed; distivalvae rounded.

Length: B, 24-27; A, 17-20; FW, 27-29; HW, 22-24.

Distribution. Japan (Iriomotejima Is.).

Remarks. This new species is very similar to S. longialata Yang, 1992 from Hunan, China in general appearance but can be distinguished from it by coloration of legs. Iriomotejima Is. is geographically very close to Taiwan, and two species of Suhpalacsa, S. formosana Okamoto, 1909 and S. umbrosa Esben-Petersen, 1913 are distributed there. However, S. iriomotensis can be easily distinguished from them by the body length of male (body length 33-37 $\mathrm{mm}$ in S. iriomotensis, whereas $25 \mathrm{~mm}$ in S. formosana and $45 \mathrm{~mm}$ in $S$. umbrosa). In having an ornamented male ectoproct, $S$. iriomotensis is similar to $S$. barrowensis New, 1984 known from Barrow Is., Australia, but can be distinguished from it by coloration of vertex and vertical hairs, presence of yellow spots on mesonotum and metanotum, hyaline cell $\mathrm{Sc}$ of wings, in male, presence of slender gonarcus, not hooked parameres, and in female by hyaline hindwing apex. S. iriomotensis shows distinct sexual dimorphism in abdominal length. Etymology. The species name refers to the type locality of this species.

\section{DISCUSSION}

S. iriomotensis has unique ventrolateral prominences of the male ectoproct, which is similar to the elongated male ectoproct observed in $S$. barrowensis. As mentioned by New (1984), these conditions are not in agreement with the original definition of Suhpalacsa, i.e., a scale-like unornamented ectoproct. However, New (1984) assigned S. barrowensis to Suhpalacsa on the basis of other diagnostic characters of Suhpalacsa and extended the genus definition (see diagnosis of Suhpalacsa). The shape of the male ectoproct varies frequently also within a genus. For example, in the subsaharan African genus Brevibarbis Tjeder \& Hansson, 1992, the male ectoprocts of B. decellei (Taschenberg, 1879) and B. decellei Tjeder \& Hansson, 1992 have a 
ventral projection, whereas that of the other species does not have such feature (Tjeder \& Hansson 1992). Here we followed the revised genus definition of Suhpalacsa by New (1984) and assigned S. iriomotensis to the genus. However, all character states that define the genus (i.e., unornamented antenna, unproduced anal margin of forewing, absence of male abdominal prominence) are widely observed in both Ascalaphidae and Myrmeleontidae, the sister group of Ascalaphidae (Aspöck et al., 2001; Aspöck 2002; Haring \& Aspöck 2004; Mansell 1992; Stange 1994), and thus are probably plesiomorphic. Moreover, no autapomorphy supporting a monophyly of the genus is known. Although it is beyond the scope of the present paper, generic definition and monophyly of Suhpalacsa must be revised in the future based on extensive sampling.

As mentioned above, S. iriomotensis and S. barrowensis are superficially similar in an apomorphic character state, the ornamented male ectoproct. However, it probably was evolved independently, because the male ectoproct of $S$. barrowensis is elongated ventrally (New 1984: figs. 195-196), whereas that of S. iriomotensis has ventrolateral prominence (Figs 2-3). Moreover, the distribution of the two species are so isolated geographically, southwestern Japan (Iriomotejima Is.) and western Australia (Barrow Is.), that the sister-group relationship between them is less likely.

\section{ACKNOWLEDGMENTS}

We thank T. R. New (Department of Zoology, La Trobe University) for critical reading of the manuscript and Issei Ohshima (SEHU) for preparation of specimen shown as Fig. 1a. K. Yoshizawa thanks M. Kinjo, T. Yasunaga and Y. Nakatani for assistance in the field.

\section{REFERENCES}

Aspöck U (2002) Phylogeny of the Neuropterida (Insecta: Holometaboloa). 
Zoologica Scripta 31, 51-55.

Aspöck U, Plant JD, Nemeschkal HL (2001) Cladistic analysis of Neuroptera and their systematic position within the Neuropterida (Insecta: Holometabola: Neuropterida: Neuroptera). Systematic Entomology 26, 73-86.

Esben-Petersen P (1913) H. Sauter's Formosa-Ausbeute. Planipennia II, Megaloptera and Mecoptera. Entomologische Mitteilungen 2, 222-228, 257-265.

Haring E, Aspöck U (2004) Phylogeny of the Neuropterida: a first molecular approach. Systematic Entomology 29, 415-430.

Kuwayama S (1962) A revisional synopsis of the Neuroptera in Japan. Pacific Insects 4, 325-412.

Kuwayama S (1964) On the Neuroptera of the Ryukyus. Insecta Matsumurana 27, $38-48$.

Leach WE (1814) Zoological miscellany; being descriptions of new, or interesting animals. Vol. 1. London.

Lefèbvre A (1842) 'G. Ascalaphe. Ascalaphus. Fabricius. vel Azesia. A Lefèbvre.' Magazin de Zoologie, d'Anatomie Comparée et de Palaeontologie ... par F. E. Guérin-Ménéville 4 (text to plate 92), 1-10. (In French.)

Mansell MW (1992) The systematic position of the Nemopteridae (Insecta: Neuroptera: Myrmeleontidae). In: Canard M, Aspöck H, Mansell MW (eds) Current Research in Neuropterology. Proceedings of the Fourth International Symposium on Neuropterology, pp 233-241. Privately printed, Toulouse, France. McLachlan R (1871) An attempt towards a systematic classification of the family Ascalaphidae. Journal of the Linnean Society of London Zoology 11, 219-276.

McLachlan R (1875) A sketch of our present knowledge of the neuropterous fauna of Japan (excluding Odonata and Trichoptera). Transactions of the Entomological Society of London 1875, 167-190.

McLachlan R (1891) Descriptions of new species of holophthalmous Ascalaphidae. 
Transactions of the Entomological Society of London 1891, 509-515.

Navás L (1900-1901) Notas entomológicas. III. Neurópteros del Montseny

(Barcelona). Actas de la Sociedad Española de Historia Natural 29, 92-96. (In Latin.)

New TR (1984) Revision of the Australian Ascalaphidae. Australian Journal of Zoology, Supplementary Series 100, 1-86.

New TR (2003) The Neuroptera of Malesia. Fauna Malesiana, vol. 4. Brill, Leiden.

Nomura S (1989) Neuropetra. In: Hirashima Y (eds) A checklist of Japanese insects, pp 189-196. Kyushu University, Japan.

Okamoto H (1909) [On the Japanese Ascalaphidae]. Zoological Magazine 21, 499-508. (In Japanese.)

Oswald JD (1988) Remarks on the taxonomy of three recently discovered generic nomina oblita in the family Ascalaphidae (Neuroptera). Neuroptera International 5, 89-92.

Stange LA (1994) Reclassification of the New World antlion genera formerly included in the tribe Brachynemurini (Neuroptera: Myrmeleontidae). Insecta Mundi 8, 67-119.

Sziráki G (1998) An annotated checklist of the Ascalaphidae species known from Asia and from the Pacific Islands. Folia Entomologica Hungarica 59, 57-72. Tjeder B (1992) The Ascalaphidae of the Afrotropical Region (Neuroptera). 1. External morphology and bionomics of the family Ascalaphidae, and taxonomy of the subfamily Haplogleniinae including the tribes Proctolyrini n. tribe, Melambrotini n. tribe, Campylophlebini n. tribe, Tmesibasini n. tribe, Allocormodini n. tribe, and Ululomyiini n. tribe of Ascalaphidae. Entomologica Scandinavica, Supplement 41, 3-169.

Tjeder B, Hansson C (1992) The Ascalaphidae of the Afrotropical Region (Neuroptera). 2. Revision of the tribe Ascalaphini (subfam. Ascalaphinae) 
excluding the genus Ascalaphus Fabricius. Entomologica Scandinavica, Supplement 41, 171-237.

Van der Weele HW (1909) Mecoptera and Planipennia of Insulinde. Notes from the Leyden Museum 31, 1-100.

Walker F (1853) List of the specimens of neuropterous insects in the collection of the British Museum, Part II [pp. 193-476].--(Sialides--Nemopterides). British Museum [Natural History], London.

Yang C (1992) Neuroptera. In: Peng J, Liu Y (eds) Iconography of forest insects in Hunan China. Pp 644-651. Academia Sinica \& Hunan Forestry Institute, Hunan, China. (In Chinese.) 
$<$ Figure captions $>$

Figure 1 Suhpalacsa iriomotensis sp. nov., paratype male, dorsal view (a) and paratype female, lateral view (b).

Figures 2-7 Male terminalia of Suhpalacsa iriomotensis sp. nov. 2 Terminalia, lateral view; 3 terminalia, dorsal view; 4 sternite IX, ventral view; 5 genitalia, lateral view; 6 genitalia, dorsal view; and 7 genitalia, ventral view. Scale lines: $1 \mathrm{~mm}$.

Figures 8-9 Female terminalia of Suhpalacsa iriomotensis sp. nov. 8 Terminalia, lateral view; and 9 terminalia, ventral view. Scale lines: $1 \mathrm{~mm}$. 


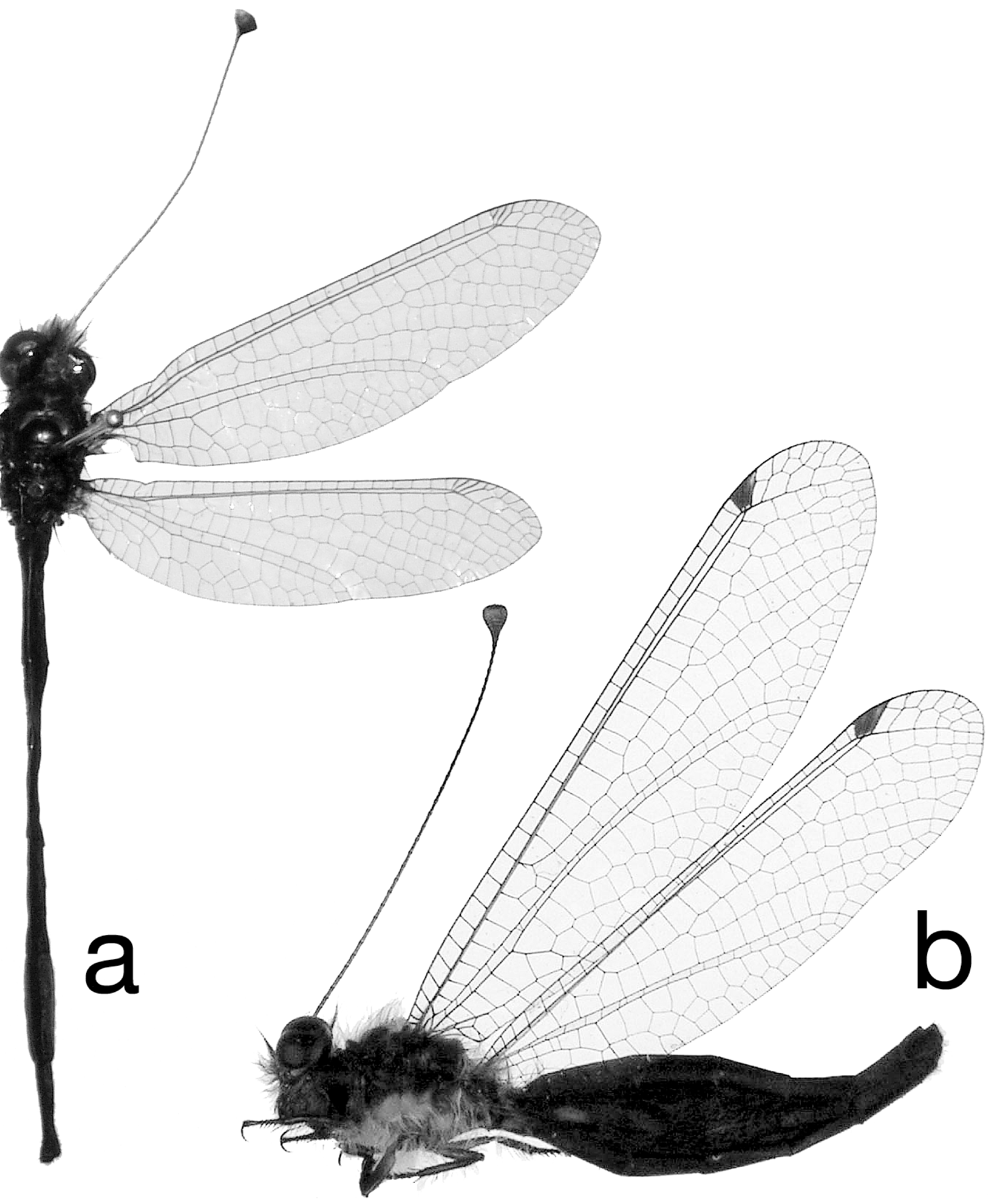



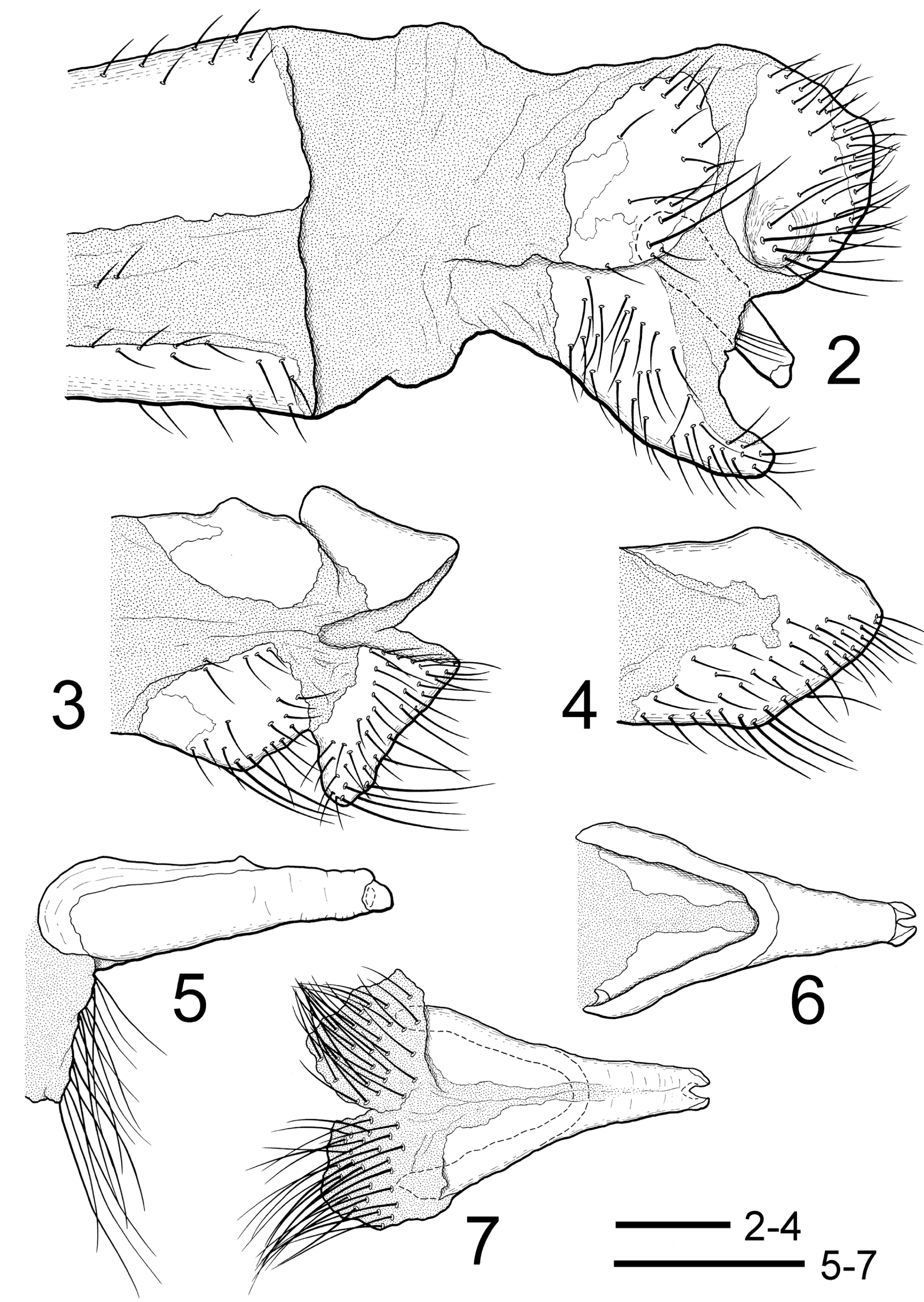
